\title{
A tale of two city halls: icons for sustainability in London and Seattle
}

\author{
D. Armpriest \& B. Haglund \\ Department of Architecture, University of Idaho
}

\begin{abstract}
Recently two great cities-London and Seattle-have built new city hall buildings with a green agenda inspired by activist mayors - Ken Livingstone and Paul Schell. Their political agendas include a focus on planning and design activities that will help transform their cities for continued viability and livability in the face of increasing environmental challenges. In London, Livingstone carved out a congestion zone to allay mounting, gridlocked automobile traffic in the central city; it costs eight pounds a day to drive into central London. Meanwhile in Seattle, the city has implemented a green building agenda (LEED silver) for all public facilities, and the city has "signed" the Kyoto Accord in defiance of the Bush administration's stance. These new city halls are intentional symbolic icons marking their evolving visions for the future. Comparing the two buildings will reveal much about the commonalities and differences in approaches to sustainability in the United States and United Kingdom.

Through the lenses of first-hand experience in the buildings, analysis of critical commentary, and comparative evaluation, we examine the mindsets of the two cultures. The analysis includes several key project characteristics that provide the basis of the comparison, including the design process, building image, public access, sustainable design strategies, and performance in these exemplar buildings.
\end{abstract}

Keywords: sustainable architecture, building performance, city halls.

\section{Introduction}

London and Seattle are both similar and different in ways we believe speak to cultural attitudes on sustainability. Both urban hubs have set an agenda for sustainable development and have used new city hall buildings as exemplars. 
However, London chooses to take the lead in a country committed to reversing global warming while Seattle pursues sustainability against the grain of national policies that frustrate efforts to address global warming. Greater London is larger (12 million to 2 million) and denser than the Seattle Metropolitan area and its mass transit is much more extensive and successful-all factors that make sustainability more palpable. On the other hand Seattle has strong visual connections to its beautiful natural setting - vistas of the Olympic Mountains, Puget Sound, and Mt. Rainier - that serve as reminders of the fragile natural environment to be sustained. Both cities are sited in mild northern climates dominated by ocean influence that moderates temperatures, provides rain and cloud cover, and places high value on daylight and sunshine. These are favorable climates for attaining energy-efficiency in office buildings.

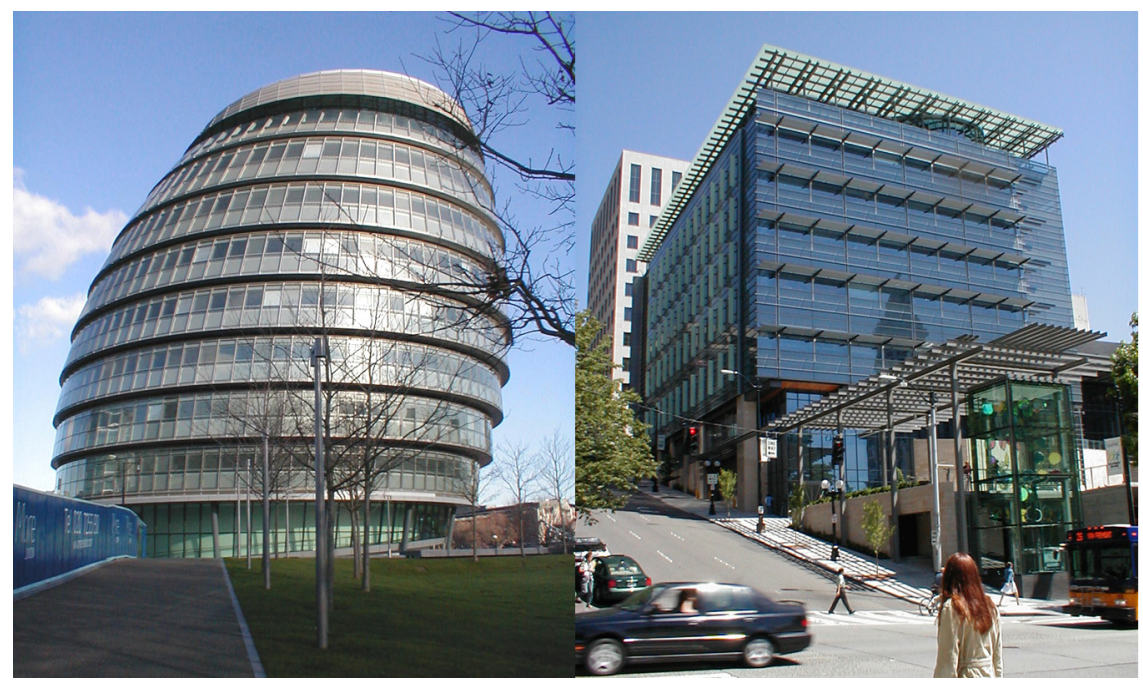

Figure 1: London City Hall viewed from the west and Seattle City Hall's office tower viewed from the northwest, comparing image and shading strategies.

The mayor's vision is for London to become an exemplary sustainable world city, based on the three balanced and interlocking elements - strong and diverse economic growth; social inclusivity, allowing all Londoners to share in London's future success; and fundamental improvements in environmental management and use of resources [8]. The Sustainable Development Framework for London, drafted by the London Sustainable Development Commission in 2002, proclaims, "We will protect and improve the city's natural ecosystems, its biodiversity, its open spaces and its built environment. We will help to protect the wider regional, national and international environments with which London has links." To this aim City Hall was designed as a sustainability exemplar, a congestion charge was enacted to discourage automobile traffic in central 
London, and new planning regulations for large-scale development in Greater London that require that $10 \%$ of its energy be provided by on-site sources. The mayor exhorts be lean, be green, be clean when chosing energy sources.

Seattle mayor Greg Nickels' Environmental Action Agenda sets three goalsto create a "lean, green city government," "healthy urban environments," and "promote smart mobility" [17]. In February, 2005, he announced, on the day the Kyoto Protocol took effect, that Seattle would commit itself to meet or beat the goals of the agreement despite the failure of the United States to join the treaty . At this time, he also appointed a Green Ribbon Commission consisting of environmental, city, and business leaders to assist him in developing the plan. The Commission is reported to be considering following London's lead in charging a fee to drive into the city [20].

\section{Design process}

\subsection{London}

A competition resulted in selecting a developer/architect team. The building was developed by More London (CIT Group) and leased to the GLA for 25 years. Designed by Foster and Partners, with Arup as structural and services engineer, it employed the UK's most renowned green design team. "We designed the building from the outside," says Foster and Partners project director Richard Hyams. The design was revised from the architect's original all glass concept, dubbed the fencing mask, in response to sophisticated computer modeling by consulting engineer Arup who produced a "thermal map" to show how the heat from the sun would travel over the building's surface throughout the course of a year. To reduce the building's cooling requirements and thus reduce the building's energy load, the architect refined the building's form to a shape that leans to the south, so as to limit the extent of façade exposed to the sun. The southern elevation, which has the greatest potential for solar gain, has also been stepped so that the floor above cantilevers to shade the floor below, fig. 1. On the northern elevation, however, free from excessive solar gain, the architects have indulged in an unshaded façade [18].

\subsection{Seattle}

The City Hall was designed by a collaborative team that combined the local talent of Bassetti Architects with the nationally recognized green firm of Bohlin Cywinski Jackson (BCJ). They were selected through a competition process, beating out the finalists, Antoine Predock and Patkau Architects. The design process included 50 public meetings and workshops and a web-based system for public input. Local architect and city councilman Peter Steinbrueck claimed "the process almost killed this design" due to the challenge of responding to the extensive criticism [22]. Architectural critic Sheri Olson claims the design, which is touted by the architects and city as being grounded in the site and regional, is actually the same scheme the architects brought to their interview 
and changed very little as a result of the process. The design team did consult with the Seattle Lighting Lab to refine natural and electrical lighting strategies.

\section{Building image}

London City Hall is an iconic building that competes for attention with nearby Tower Bridge and the Tower of London and is framed by the reflective background of More London, a commercial project Seattle City Hall is more modest in appearance, serving as background for its iconic neighbour, the Seattle Public Library. Both city halls were designed not only to demonstrate sustainable design, but employ generous glazing to portray an open and accessible city government, fig. 1 .

\subsection{London}

According to Foster and Partners, "City Hall has been designed as a model of democracy, accessibility, and sustainability." [1]. Its eleven stories and 185,000 square feet $\left(18,000 \mathrm{~m}^{2}\right)$ house both the Chamber of the London Assembly (25 elected members) and the offices of the Mayor and 500 staff of the Greater London Authority, providing about 370 square feet per person. Completed in May 2002, it cost about $\$ 64,000,000$ or $\$ 345$ per square foot. The building has achieved an excellent rating in the BREEAM assessment.

\subsection{Seattle}

The new City Hall is a seven story, 200,000 square foot building that houses the mayor, city council and a staff of 320 . There are two stories of parking below ground, the majority of which are reserved for alternative fuels and carpooling vehicles. It was completed in 2003 for a cost of \$72,000,000 and recently received a LEED Gold rating. As designed, the building provides 625 square feet per person, and cost $\$ 320$ per square foot. The language used by city officials to describe the Seattle City Hall stated aspirations similar to those used to describe the GLA: "to invite citizen participation in city government... celebrate the magnificence of our natural beauty..., incorporate public art...[be] a model for sustainable design and...serve the city for the next 100 years" [6].

The Seattle City Hall is one of five new or renovated buildings that form the Seattle Civic Center. It is a light and open structure with views to city, Puget Sound, and the Olympic Mountains. (It replaced the 1950s City Hall building that was characterized by small, dark, and cluttered spaces). BCJ describes the final building scheme as "a seven-story glass office block, a metal Council Chamber, and a lobby of transparent and translucent glass uniting the two. This transparency reflects the goal of an open, accessible city government, easily identified, where ordinary citizens can locate city services. The curved metal volume of the City Council Chamber is a modern form that evokes a civic dome." [4]. 


\section{Public access}

\subsection{London}

"The ramps were conceived so that the public could see democracy in action by looking down at assemblies in progress. But in practice, when the assembly chamber is in use, people are barred from using the spiral ramps or even opening or shutting doors leading on to them because of the distracting noise." [21]. Furthermore, except for occasional weekends, the general public is not welcome to the upper floors and when invited is subject to a security check. The lobby and lower floor are publicly accessible.

The building is surrounded by public outdoor spaces that are paved in charcoal-gray limestone, exploit the riverbank site, and project a suitably civic character. On the west side lies a shallow amphitheatre, or "Scoop", which can be reached from both the riverside walk above and the basement restaurant below. Tourists and local office workers find it an inviting bowl in which to take a break. Free musical events at lunchtime and dramatic performances in the evening are regularly staged for audiences of up to 1000 people. The Scoop is bounded on two sides by an external exhibition area and a model of the world. While the river walk and amphitheater are successful, the site's large lawns are not inviting nor up to London's expectations for parks [21].

\subsection{Seattle}

The Seattle City Hall was designed to be barrier free, and also includes a number of spaces designed specifically for social interaction and "community building." [6]. The Grand Stairs provide seating as well as access to the Plaza and City Council chambers. City Council meetings can be televised to visitors in the lobby, and a fireplace and piano are also tucked away in a niche adjacent to a large meeting room. The lobby is large and open, providing visual and physical connections throughout the building, and the mayor's office on the top floor is open to all comers. Public art is also highlighted in four installations at the lobby level. There are no security checkpoints in the building, so it is fully accessible to the public.

The recently completed Fourth Avenue Plaza on the site's southwest corner, together with the Grand Stair and Lobby provide a link and rest stop for people moving up the steep hill climb between a major public transit stop and the civic center. Like London, Seattle values its public parks and urban spaces, but the new Plaza has been criticized as a missed opportunity to be "a dramatic, all-things-to-all-people plaza that's equally suited to private contemplation or noisy demonstrations." [16].

\section{Sustainable design strategies}

\subsection{London}

The design team's intention was to cut energy consumption by a novel combination of architectural form and natural energy sources. Although the 
building's efficient spherical shape reduces the external envelope by $25 \%$, it was originally conceived to be all glass, the most thermally permeable material. Arup's solar studies convinced the architect to reduce the glazing to $25 \%$ of the façade of the east, south, and west-facing office floors. The remaining $75 \%$ is made of insulating panels with a glazed exterior face [2]. The shifted floor plates that form south-facing overhangs to cut solar gain in summer are less than moderately effective. The building's more effective shading devices are the usercontrolled louvers housed between the panes of double glazing.

The environmental system combines displacement and natural ventilation and perimeter heating. Cooling is provided by chilled beams that avoid conventional refrigerants and instead draw naturally cool water from two $50 \mathrm{~m}$ deep boreholes, which also greatly reduces electrical consumption and avoids $\mathrm{CO}_{2}$ emissions. It uses a quarter of the power needed for a conventional airconditioning system. The expended borehole water is used for flushing toilets and grounds irrigation purposes and excess is discharged into the Thames. In the GLA's hybrid natural ventilation and air-conditioning scheme, the occupants can open the windows, to enjoy fresh air, providing them with some control over their environment. Opening the windows switches off the local air-conditioning, saving energy. On the fully glazed north façade, which affords spectacular views of the London skyline from the council chamber and the ramp above, cooling and heating are provided by cool ground water or heated water passing through the $300 \mathrm{~mm}$ diameter core of the horizontal primary steelwork of the structural diagrid, which becomes a series of giant tubular radiators. In the winter, some warmth is provided by recycling heat from people and office equipment. Air extracted from the offices passes through a heat exchanger that heats the incoming fresh air, supplied to the offices via a floor plenum at a low velocity to minimize the energy needed to power the fans. A gas boiler provides additional heat when required through trench heaters around the building's perimeter [2, 9].

The curved office façade with user-controlled louvers puts all the workers close to apertures they can control for light and glare. The success of this daylighting strategy is highlighted by the occupants' complaints about the contrasting, gloomy, un-daylighted committee rooms in the basement.

Green transportation is encouraged by the site design. No apparent car parking is provided near the building (it's under the green roof of the south lawn) nor do any roadways approach the building. The most obvious and attractive approach to the building is via the Thames-side walk.

In 2005 "GLA facilities management received a $£ 270,000$ grant from the DTI to go ahead with the $£ 500,000$ scheme, which will convert light energy into electricity using the curved roof. Allan Jones, chief development officer for the London Climate Change Agency, which helps the mayor reduce carbon emissions in the city, said City Hall was built with the intention of installing photovoltaic panels at a later date." [12]. These roof-mounted photovoltaics should generate up to $81 \mathrm{~kW}$. 


\subsection{Seattle}

The goals for sustainable design at the City Hall include providing connection to the outdoors, conserving energy and water, the use of sustainable materials, providing healthy indoor spaces, minimizing traditional effects of new buildings in an existing urban structure, "long-life, loose-fit," and "smart mobility" [6].

More specifically, strategies include extensive use of natural light. Each façade is designed based on solar orientation and microclimatic factors. The north façade is fully glazed with translucent vertical fins that provide shade during the six month period it is exposed to direct sun. The lower council chamber's south façade has wide horizontal louvers while the tower is shaded by a curving wall of fritted glass. The primary circulation space for each floor flanks the façade, providing public views to the green roof below while providing a buffer against solar gain. The west façade is protected by operable interior shading devices, and the east side which is shaded by the adjacent justice center features smaller punched openings. Small floorplates mean that most workers are able to sit close to a window. Strategies used to conserve energy include high efficiency HVAC equipment and a raised-floor displacement ventilation system. Electrical loads are minimized as a result of the design of the façade to optimize daylighting and reduce requirements for electrical lighting.

Water conservation measures include waterless urinals, low flow lavatories and toilet fixtures. Rainwater run-off is collected in cisterns below the building, and used to water plantings and for toilet flushing. In addition, a large green roof detains rainwater during winter, reducing stormwater discharge, but also thrives without water during the dry summer months. Many of the materials came from local or regional sources and include recycled content. There has been some controversy; however, about the contra-sustainable use of titanium to clad the city council chambers (in an effort to pay homage to Boeing), and imported limestone cladding. In keeping with the concept of smart mobility, there is no public parking available on site; however, there are multiple connections to public transit and accommodations for pedestrian access.

\section{Building performance}

To assess building performance we have had to rely on evaluation by interested third parties-Building magazine [12,21] for the GLA building and the Seattle Post-Intelligencer $[13,14]$ for the SCH. Meanwhile, in the UK after it comes in force on 6 April 2006 the Energy Performance of Buildings Directive will oblige public authorities to publish energy consumption data; and in Seattle an extensive post occupancy evaluation, now underway, will assess 20 environmental, social and economic indicators, providing a very broad view of City Hall's performance.

\subsection{London}

"City Hall does not meet its target of using one quarter of the energy for airconditioning required by comparable office buildings. Last year, it came in at $8 \%$ 
above the government's good practice guide for total energy usage, partly because the building is used more intensively than originally intended. (In the first three years of its life, the number of building occupants has grown to 650, well above the 426 for which it was designed) Even so, it still undercuts a similar prestige office building by $34 \%$, and it exploits the renewable energy sources of ground water for cooling, and in the near future, photovoltaic cells for electricity." [21]. The total energy in gas and electricity consumed during the financial year $2004 / 5$ was $376 \mathrm{kWh} / \mathrm{m}^{2}$ of environmentally controlled floor area- $-50 \%$ above the energy consumption target of $250 \mathrm{kWh} / \mathrm{m}^{2}$ set at the design stage [21].

"City Hall is one of a number of high profile green buildings that have struggled to live up to their green credentials. Foster's Swiss Re and Hopkins' Portcullis House have also been found to perform better on paper than in practice. This discrepancy has been blamed on building managers, who critics say have yet to come to grips with how to run low-energy buildings. Energy experts at BRE blame a lack of communication between architects and facilities management for the shortfall in performance. A GLA spokesman said the building was using more energy for two reasons - first because it housed more people than it was designed to do and, second, because it was also used as a conference centre and tourist attraction." [12].

\subsection{Seattle}

The Seattle City Hall was designed to achieve LEED silver certification, but after the building was completed and documented, it was found to have gained the higher rating of LEED gold even though photovoltaics, that were an original part of the design, have yet to be installed. However, the Seattle PostIntelligencer proclaimed "Seattle's new City Hall is an energy hog" in the July 5, 2005 issue [13]. The article claimed, based on data provided by the local utility, that energy costs for operating the building ranged from " $15 \%$ to $50 \%$ higher than for the older building that was replaced." Closer review of the data indicates the new City Hall had lower overall electrical costs between May and mid-July, but was otherwise much more expensive to operate, especially in winter and spring. There has been much speculation about the causes of this situation- the building managers haven't figured out how to run the system, there are many high ceilings and open spaces that must be heated in winter, and there are fewer occupants per square foot in the new city hall than in the old.

\section{Conclusion}

By examining these two buildings we've observed that even though the national political context (Kyoto and not) and architectural expression (internationalism vs. regionalism) contrasted, the strategies to attain sustainability are quite similar - a combination of low-tech strategies and advanced HVAC systems, attention to shading, incorporating daylighting, encouraging public use, and discouraging automobile access. Both buildings were initially praised for their ambitious green agendas. However, choosing to create an icon of sustainable 
design attracted critical attention. After the initial honeymoon of public praise both buildings have encountered criticism for not truly attaining their lofty goals and both are undergoing assessment and evaluation for self-improvement.

Should we be dismayed by this fall from public grace? No, not only do the two City Halls serve as exemplars of sustainability, but through public scrutiny, they also provide a template for a process that truly defines sustainable building. Sustainable buildings must be designed to be sustainable, must be commissioned to ensure that design intentions were met by the systems and features installed, must be assessed for fitness after they have be occupied for a year or two, and must be periodically re-evaluated.

Both of these buildings have suffered "successful building" syndrome-their popularity and quality has attracted wider use than anticipated. So far design teams are fairly good at the design and improving on commissioning activities, but tend to walk away from the building after it's completed, ignoring the lessons that could be learned from its occupancy. It is clear that when people occupy buildings they change the buildings' behaviour and much of the criticism that both City Halls have encountered is as a result of their evolving patterns of use. Occupancy is not a predictable or constant state but changes continually over time, suggesting that a feedback loop is needed to determine the effects of occupancy on building performance (and coincidentally occupant performance). This evaluation can be accomplished by periodically assessing their performance as the building ages and each time occupancy patterns are significantly altered in order to adjust their operations and remodel their systems and features in response. The lessons learned from these assessments can also be used to improve future architectural and systems design. This system of stewardship and learning is the hallmark of long-term sustainability and is necessary to propel us into a future where the earth's resources are not only sustained but regenerated, ensuring a joyful existence for future generations.

\section{References}

[1] Arup, Designing City Hall, self-published brochure.

[2] Barker, Don, "Foster's New City Hall." Architecture Week, 26 March 2003.

[3] Bassetti Architects web page, www.bassettiarch.com.

[4] Bohlin Cywinski Jackson web page, www.bcj.com.

[5] Better Bricks, "Seattle City Hall Case Study" Northwest Energy Efficiency Alliance, www.betterbricks.com.

[6] City of Seattle, "Seattle City Hall" Brochure, 2003.

[7] City of Seattle, Seattle Municipal Civic Center Master Plan, June, 1999.

[8] GLA web site, "A Sustainable Development Framework for London," www.london.gov.uk.

[9] Lane, Thomas, “Keeping Ken cool,” Building, October 12, 2001.

[10] Merkel, Jayne, "City Hall, London, England," Architectural Record, 02 2003. 
[11] Miller, Brian, "Best Municipal Makeover," Seattle Weekly, August 4, 2004.

[12] Miller, Vikki, "City Hall to add solar panels to boost green performance," Building, September 16, 2005

[13] Mulady, Kathy, "Seattle's new City Hall is an energy hog," Seattle Post Intelligencer, July 5, 2005.

[14] Mulady, Kathy, "Energy audit of Seattle City Hall sought," Seattle Post Intelligencer, August 2, 2005.

[15] Office of Mayor Greg Nickels, "Mayor calls for Seattle, other cities to meet protocol goals" News Advisory, February 16, 2005.

[16] Olsen, Sheri, “On Architecture: Confusion trumps beauty at Seattle's new City Hall”. Seattle Post Intelligencer, September 8, 2003.

[17] Paladino \& Company, Inc. LEED Performance Evaluation Plan: Seattle Justice Center and City Hall, December 31, 2003.

[18] Pearson, Andy, “It's a wrap,” Building, September 21, 2001.

[19] Seattle City Light, "City Hall Energy Usage" table published in Seattle Post-Intelligencer, July, 2005.

[20] Shogren, Elizabeth, "Seattle Tackles Greenhouse Gases" NPR Morning Edition, November 28, 2005.

[21] Spring, Martin, "Time has told," Building, October 21, 2005.

[22] Steinbrueck, Peter, in an interview entitled "City Hall and the Legacy of New Public Architecture”, Arcade Magazine 22.2, March 2003. 